\title{
Investment Incentives as a Mediator in the Relationship between Macroeconomic Variables and Growth of Private Domestic Investment in Kenya
}

\author{
Monica Wanjiru Kinyanjui ${ }^{1}$, Prof. Willy Muturi² \\ and Dr. Agnes Njeru ${ }^{3}$
}

\begin{abstract}
The objective of this study was to investigate the mediating effect of investment incentives on the growth of private domestic investment in Kenya using time series data for the period 1997 to 2018. To test for mediating effect, the study used (Baron \& Kenny, 1986) approach which propose a four-step procedure in which several regression analyses were conducted and the significance of the coefficients examined. The results did not consistently support a full mediation hypothesis, given that the coefficients did not consistently change in magnitude and significance. Therefore, the study does not reject the null hypothesis that investment incentives do not meditate on the relationship between macroeconomic variables and the growth of private domestic investment in Kenya. The results of this study will benefit policy makers by providing them with data-based evidence that will guide them in making appropriate policies that encourage growth of private domestic investment in Kenya and institute proper management of private domestic investments to boost economic growth in Kenya.
\end{abstract}

Keywords: Tax expenditure, Investment tax expenditure, Investment tax credit, Private domestic investment.

\footnotetext{
${ }^{1}$ Department of Economics, Account \& Finance,Jomo Kenyatta University of Agriculture and Technology.

2 Department of Economics, Account \& Finance,Jomo Kenyatta University of Agriculture and Technology.

${ }^{3}$ Department of Economics, Account \& Finance,Jomo Kenyatta University of Agriculture and Technology.
}

Article Info: Received: December 23, 2020. Revised: January 21, 2021.

Published online: January 25, 2021. 


\section{Introduction}

The growth in private domestic investment has been recognized as a promoter of economic growth of any economy. The level of domestic private investment is influenced by resource mobilization, which also depends on the macroeconomic environment of any economy (Lawrence \& Funso, 2018). Kalu \& Onyinge (2015) opines that private sector investment is the number one catalyst for economic growth, whereas the public sector is tasked with providing a conducive environment. This is because private investment forms an important portion of the Gross Domestic Product (GDP), when investment grows, GDP also grows (Altaleb \& Alokor, 2012). To be able to stimulate and sustain economic growth, it is paramount that developing countries have a private investment as a significant portion of GDP (CBK \& World Bank, 2017). According to Gillis, Perkins, Roemer and Sodgrass (1987), private investment as portion of GDP should not be less than 15 at any given time, whereas the target percentage of private investment should be at least $25 \%$ of GDP.

With a stated government policy objective of achieving an average economic growth rate of 10 percent per annum, investment levels should be above 32 percent of the GDP, with public investment being above 9 percent of the GDP and private investment being above 24 percent of the GDP (ROK, 2012). The growth in private domestic investment has been identified as a promoter of economic growth of any economy. The level of private domestic investment is influenced by resource mobilization, which also depends on the macroeconomic environment of any economy (Lawrence \& Funso, 2018).

Investment incentives are quantifiable economic benefits provided by government to entrepreneurs with an aim to promote investment and direct them to specific sectors of the economy (Gitonga, 2017). United Nations (2010) notes that these incentives can be categorized as either fiscal or non-fiscal. Fiscal benefits include tax concessions, while non-fiscal benefits include loans and grants. The previous few decades have been characterized by massive efforts by government to make the country investment hub for both foreign direct investment and private investments. In this regard, the government has embarked on formulation of policies and incentives that are meant to attract investors into the country. Investors are set to enjoy tax incentives yet another strategy to promote investment (Abdulla, Othman, \& Hongzhong, 2012).

Tax expenditure or tax incentive refers to tax revenue foregone due to tax deductions, tax exclusions, tax credits, and reduced tax rates for certain activities, industries, or taxpayers (Berger, \& Rohaly, 2017). Tax incentives are normally geared towards certain economic goals such as attracting and retaining investment and social goals such as cushioning households in a low-income segment from the excessive tax burden (Chetty and Hendren, 2013). Since independence, Kenya has incentivized trade and investment specifically to promote domestic investment, exports and attract Foreign Direct Investment (FDI) (Institute of Economic Affairs, 2012). 


\subsection{Statement of the Problem}

The vision 2030 economic pillar aims to achieve an average economic growth rate of 10 percent per annum and sustaining the same until 2030 (GOK, 2012). Sufficient economic growth of at least $7 \%$ is needed so as to achieve the sustainable development goals. This will be made possible by a thriving private sector, which is also crucial for poverty reduction in any country (World Bank, 2017). The envisioned economic growth is anchored on increase in private and public investment specifically, private investments were expected to rise from $15.6 \%$ of GDP in $2006 / 07$ to $22.9 \%$ in $2012 / 13$, and to over $24 \%$ of GDP during the period 2020/21 to 2030 (KIPPRA, 2017). At 4.3\% of GDP in 2016 and 5.3\% of GDP in 2017, this remains below $12 \%-15 \%$ required to sustain a robust private investment for economic growth (World Bank, 2017). Notably, Kenya's Private sector investment has continued to perform below expectations (Kanyua, 2014).

Several studies have been conducted on growth of domestic private investment in Kenya. Gachoki and Nyang'oro (2016) studied the impacts of capital flight on private investment in Kenya, Mwenda (2017) researched how to strengthen a vibrant domestic investment market for economic growth in Kenya, Kamundia (2015) studied the effects of public debt on private investments and economic growth in Kenya, Mbaye (2014) researched on determinants of domestic private investments in Kenya, Njuru (2012) studied the effects of fiscal policy on private investments in Kenya, Cherono (2013) researched on the effects of remittances and financial development on private investment in Kenya. From the literature reviewed, it is worth noting that little attention has been paid to the mediating role of investment incentives on the relationship between macroeconomic variables and growth private domestic investment in Kenya. This study will fill in on this existing knowledge gap.

\subsection{Specific Objectives of the study}

1. To determine the mediating effect of investment incentives on the relationship between macroeconomic variables and growth of private domestic investment in Kenya.

\subsection{Research Hypotheses}

$\mathrm{H}_{01}$ : Investment incentives do not mediate on the relationship between macroeconomic variables and growth of private domestic investment in Kenya.

\section{LITERATURE REVIEW}

\subsection{Theoretical Review}

\subsubsection{Keynesian Theory of Investment}

Keynes (1936) laid emphasis on the central role of investment as a driver influencing aggregate output, employment and short term fluctuations in economic activities. The theory is based on marginal efficiency of capital and liquidity preference pillars. The theory stresses that investment is as a result of firms 
matching the expected return on new capital, referred to as the marginal efficiency of capital (MEC), and with the cost of capital, which depends principally on the real interest rate. Keynes articulated an investment function of the form $\mathrm{I}=\mathrm{I} 0+\mathrm{i}(\mathrm{r})$, where $\mathrm{I}$ is investment, $\mathrm{I} 0$ is autonomous investment and $\mathrm{i}(\mathrm{r})$ is interest rates. The theory put forward that investment is inversely proportional to interest rates. The higher the interest rate, the less likely the firm will be willing to undertake any given investment project. Keynes stated that firms rank various investment projects depending on the internal rate of return (IRR), or marginal efficiency of investment.

\subsubsection{Neoclassical Flexible Accelerator Theory}

The basic assumption of the flexible accelerator principle is that investment is a function of the level of output and the user cost of capital. The user cost of capital is, however, dependent on the price of capital goods, the real interest rate, and the rate of depreciation of capital assets.

This theory also links monetary and fiscal policy adjustment to investment (Olweny \& Chiluwe, 2012). If expansionary fiscal policy (high government spending and low personal tax policy) is combined with a tax policy such as a greater investment tax credit will promote private investment. Secondly, the expansionary fiscal policy raises the level of income and expected output of the firms and will therefore raise the level of desired capital stock and hence stimulate investment. On the other hand, expansionary monetary policy lowers interest rate, which would reduce rental cost of capital and will increase the desired capital stock, (Mundia, (2015); Hassan (2015).

\subsection{Conceptual Framework}

The key variables in this study were put in a conceptual framework and categorized as independent, mediator and dependent variables. This study investigated the mediating role of investment incentives on the relationship between macroeconomic variables and growth of domestic private investment in Kenya. The variables in the conceptual framework were derived from the theories identified in this study.

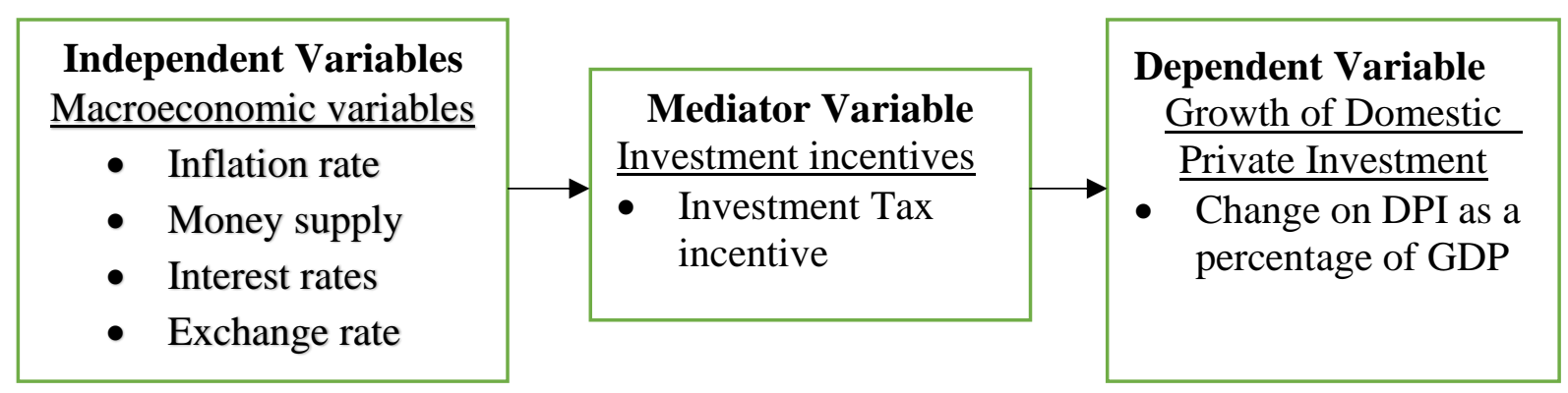

Figure 1: Conceptual framework 


\subsection{Macroeconomic Variables, Investment Incentives and Growth of Domestic Private Investment}

Gitonga (2017) defines investment incentives as quantifiable economic benefits provided by the government to entrepreneurs with an aim to promote investment and direct those to specific sectors of the economy. United Nations (2010) notes that these incentives can be categorized as either fiscal or non-fiscal. Fiscal benefits include tax concessions, while non-fiscal benefits include loans and grants. The previous few decades have been characterized by massive efforts by government to make the country investment hub for both foreign direct investment and private investments. In this regard, the government has embarked on formulation of policies and incentives that are meant to attract investors into the country. Investors are set to enjoy tax incentives yet another strategy to promote investment (Abdulla, Othman, \& Hongzhong, 2012).

The Kenya Revenue Authority (2018) characterizes the tax incentive as an arrangement that grants any individual or action positive conditions that stray from the typical arrangements of the tax enactment. This affects the individual in a constructive way, for that individual or action or any measure that accommodates a better tax treatment of specific exercises or sectors contrasted with what is accessible to the general business. Tax incentives may take various structures. In Kenya, tax incentives incorporate, tax occasions, investment stipends, and tax credits, accelerated deterioration, extraordinary zones, investment sponsorships, tax exceptions, decreases in tax rates and backhanded tax incentives.

Generally, tax incentives greatly play a significant role in attracting private investment in developed countries. Conversely, it is not the same case in developing countries where majorconcern is attributed to loss of much needed revenue by the government (Githaiga, 2013). Various countries governments have greatly been engaged in dynamic processes intended to experiment range of tax incentives that will be capable of stimulating Private investment, boosting economic growth, production expansion and promoting technological transfer. Since taxes have a significant influence on the net return on capital it is then the mandate of governments to ascertain they influence the capital movements among other countries (Thuita, 2017). One of the objectives of this study is to explore if investment incentives mediates the relationship between macroeconomic variables and domestic private investment.

\section{Review of Empirical Studies}

Babar, Awan, and Nadeem, (2017), studied the relationship between investment and corporate tax in Pakistan. The time series data for the period 1984-2014 was used for the study. Auto Regressive Distributed Lag (ARDL) technique was applied in the econometrics analysis. Results showed that private investment in Pakistan was mitigated by higher corporate tax rate. High tax rate for corporate sector reduces the corporate profits while increasing the operational cost; hence it discourages private investment. The study recommended that corporate tax rate should be decreased to 
enhance private investment.

Munongo (2015) investigated the tax incentives effectiveness to attract private investment. This study involved a case study on Southern African Development Community (SADC). In respective to the research findings, tax incentives are significant in attraction private investment inflows in the SADC countries; as a result, in order to ensure sustainable private investment into the region, tax mix which is effective will be capable of ensuring efficient use of tax incentives. Additionally, it was also important to articulate good governance to increase private investment inflows in the region. On the other hand, the study made some recommendations that SADC infrastructure needs consistence improvement to ensure foreign investment dynamic nature is sustained. Also, if they develop other financial markets they will be able to ensure that there is effective flow of capital and growth in economies by gaining more investment.

Musyoka (2012) carried out an investigation to find out the relationship between tax incentives and private Investment. The study employed data from a period of ten years that included investments incentives, trade related incentives, import duty exemption as well as FDI inflows. Dispersion in the dataset was measured using the measure od dispersion methods which included measures of variability (sd), measure of central tendency (mean), and measures of relative frequencies. The relationship between the response variable and the explanatory variables was determined by the regression and correlation analyses. The study findings revealed that tax incentives led to major losses of revenue by the government.

Gumo (2013) conducted a research to examine the effect of tax incentives on private Investments in Kenya. The study concluded that tax incentive would have a positive resultant effect on private investment and recommended that Government need to evaluate its tax incentives policy, and weigh against the benefits that accrue with the intention of spurring investment including introducing evidence based tax incentives that would minimize tax evasion.

\section{Methodology}

This study adopted causal research design. The sampling frame consisted of licensed local and internationally recognized data collection institutions and agencies. Purposive sampling was adopted to select secondary data for the period 1997 -2018. Panel data OLS regression model was used to test the Baron and Kenny (1986) conditions to examine the mediating effect of investment incentives on the relationship between macroeconomic variables and growth of domestic private investment in Kenya. A variable may be referred to as a mediator "to the extent that it accounts for the relation between the predictor and the criterion" (Baron \& Kenny, 1986). The proxies for macroeconomic variables used in this study were inflation, interest rates, money supply and exchange rates. The below two diagrams capture the Baron's Model diagrammatically. Path c in Figure 2 below is called the direct or total effect which is unmediated. $\mathrm{X}$ represents macroeconomic variables and $\mathrm{Y}$ growth in domestic private investment. 


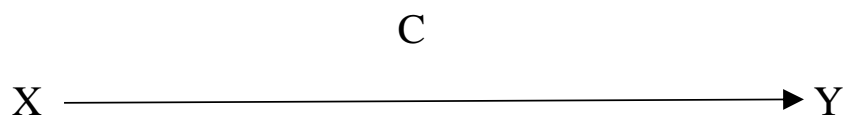

Figure 2

The effect of $\mathrm{X}$ on $\mathrm{Y}$ might be mediated by a process or mediating variable $\mathrm{M}$ and the variable $\mathrm{X}$ might still affect $\mathrm{Y}$. The mediated model is as shown in Figure 3 below;

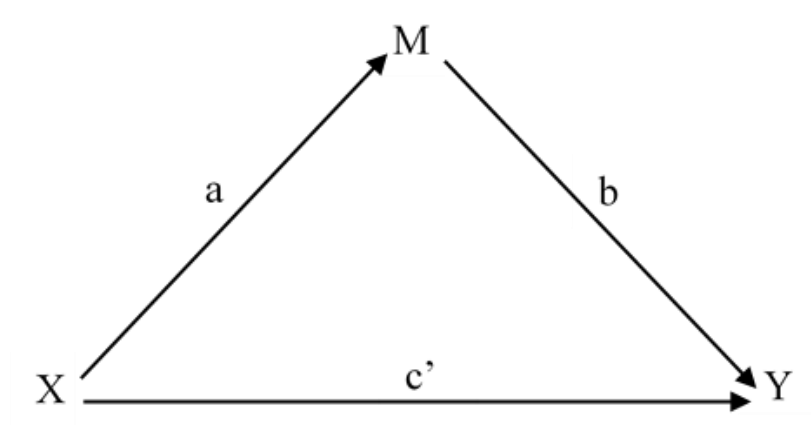

Figure 3

Baron and Kenny (1986) projected a four-step approach where several regression analyses were conducted and significance of the coefficients examined at each step. In step 1, Baron and Kenny suggested to conduct a regression analysis with $\mathrm{X}$ (macroeconomic variables) predicting Y (growth of domestic private investment) to test the total effect pronounced by path c alone. Step 2 conducted a regression analysis with $X$ (macroeconomic variables) predicting $M$ (investment incentives) to test for path a. Step 3 conducted a regression analysis with $\mathrm{M}$ (investment incentives) predicting Y (growth in domestic private investments) to test the significance of path $\mathrm{b}$ alone. Step 4 conducted a multiple regression analysis with $\mathrm{X}$ (macroeconomic variables) and $\mathrm{M}$ (investment incentives) predicting Y (growth in domestic private investments), to test the significance of path 'c'. Path $\mathrm{c}^{\prime}$ is known as the direct effect. Complete mediation is the case in which variable $X$ no longer affects $\mathrm{Y}$ after $\mathrm{M}$ has been controlled hence path $\mathrm{c}^{\prime}$ is zero. Partial mediation occurs when the path from $\mathrm{X}$ to $\mathrm{Y}$ is reduced in absolute size but is still different from zero when the mediator is introduced.

Baron and Kenny (1986) put forward that full mediating effect is seen if the following four conditions are seen. The first condition is satisfied if the independent variable (macroeconomic variables) directly affects the mediator (investment incentives). The second condition will be met if the mediator (investment incentives) affect the dependent variable (growth in domestic private investments). The third condition is satisfied when the independent variable (macroeconomic variables) directly affects the dependent variable (growth in domestic private investments) once the mediator is scrapped from the model. Lastly, full mediation will be 
supported if the direct path from the independent variable to the dependent variable becomes insignificant, when the paths to and from the mediator are once again included in the model. If all four of these steps are met, then the data are consistent with the hypothesis that $\mathrm{M}$ completely mediates the $\mathrm{X}-\mathrm{Y}$ relationship, and if the first three steps are met but the Step 4 is not, then partial mediation is indicated.

\section{Result and Discussion}

\subsection{Descriptive statistics}

Table 1 shows a summary of descriptive statistics for the targeted variables in the study. From the analysis, the average investment tax incentive (INVEST_INCENTIVES) was 8.59133 ranging from 8.884688 to 9.412505 and a standard deviation of 0.614294 for the period of analysis. Regarding growth in domestic private investment (DPI_GDP), the average growth was $7.75 \%$ ranging from $-22 \%$ and $33 \%$.

Table 1: Descriptive statistics

\begin{tabular}{|l|c|c|}
\hline & DPI_GDP & LNINVEST_INCENTIVES \\
\hline Mean & 7.75 & 8.59133 \\
\hline Median & 9.34 & 8.884688 \\
\hline Maximum & 33.08 & 9.412505 \\
\hline Minimum & -22.47 & 7.789567 \\
\hline Std. Dev. & 10.82 & 0.614294 \\
\hline Skewness & -0.66 & -0.078761 \\
\hline Kurtosis & 4.77 & 1.196224 \\
\hline Jarque-Bera & 13.90 & 10.24507 \\
\hline Probability & 0.0009 & 0.05961 \\
\hline
\end{tabular}

To test for mediating effect, the study used (Baron \& Kenny, 1986) approach, which proposed a four-step procedure in which several regression analyses were conducted and the significance of the coefficients examined. Generally, mediation analysis is comprised of testing various chains of impact using regression. These are; $\mathrm{X} \rightarrow \mathrm{Y}, \mathrm{X} \rightarrow \mathrm{M}, \mathrm{M} \rightarrow \mathrm{Y}$, and $\mathrm{X}+\mathrm{M} \rightarrow \mathrm{Y}$, where $\mathrm{X}$ is a set of macroeconomic variables, $\mathrm{Y}$ is the predicted variable (growth private domestic investment), while $\mathrm{M}$ is the mediating variable, in this case, investment incentives.

The first step is to determine if there is a relationship between the macroeconomic variables $(\mathrm{X})$ and private domestic investment $(\mathrm{Y})$. This is determined by estimating 
a long-run model as depicted in Table below. The first step is to determine if there is a relationship between the macroeconomic variables $(\mathrm{X})$ and private domestic investment (Y). This is determined by estimating a long-run model as depicted in Table 2 below.

Table 2: Long-run model

\begin{tabular}{|c|c|c|c|c|}
\hline \multicolumn{5}{|c|}{$\begin{array}{l}\text { Dependent Variable: DPI_GDP } \\
\text { Sample: 1997Q1 2018Q4 } \\
\text { Included observations: } 88\end{array}$} \\
\hline Variable & Coefficient & Std. Error & t-Statistic & Prob. \\
\hline CBK_RATE & -0.324976 & 0.119550 & -2.718333 & 0.0081 \\
\hline L_RATE & -0.128921 & 0.077202 & -1.669904 & 0.0989 \\
\hline LNCPI & 34.35384 & 4.037375 & 8.508954 & 0.0000 \\
\hline LNM1 & 8.259568 & 2.661941 & 3.102836 & 0.0027 \\
\hline LNNEER & -10.86511 & 3.257047 & -3.335877 & 0.0013 \\
\hline REPO & 0.224084 & 0.094690 & 2.366493 & 0.0204 \\
\hline TBILL & -0.009916 & 0.100594 & -0.098576 & 0.9217 \\
\hline $\mathrm{C}$ & -147.9843 & 32.17958 & -4.598702 & 0.0000 \\
\hline @TREND & -0.939964 & 0.084067 & -11.18119 & 0.0000 \\
\hline R-squared & 0.745242 & & & \\
\hline Adjusted R-squared & 0.719444 & & & \\
\hline F-statistic & 28.88726 & & & \\
\hline Prob (F-statistic) & 0.000000 & & & \\
\hline
\end{tabular}

DPIG_GDP $=-0.3249 *$ CBK_RATE $-0.1289 *$ LENDING_RATE $+34.3538 *$ LNCPI $+8.2595 *$ LNM1 $10.8651 *$ LNNEER + $0.2240 *$ REPO - $0.0099 *$ TBILL - 147.9843 - $0.9399 *$ @ TREND

All the variables in the base model are statistically significant at a 5\% level apart from the T-bill rate which has a p-value of 0.9217 .

The second step, as suggested by Baron \& Kenny, 1986 is to regress the set of independent variables ( $\mathrm{X}=$ macroeconomic variables) on the hypothesized mediating variable ( $\mathrm{M}=$ investment incentives). The results in Table 3 below show that all the variables are statistically insignificant at a $10 \%$ level, implying that they do not explain the variations in the investment tax incentives. 
Table 3: Mediating regression with investment tax incentives as the predicted variable

\begin{tabular}{|c|r|r|r|r|}
\hline $\begin{array}{l}\text { Dependent Variable: LN_INV_INC } \\
\text { Sample (adjusted): 2000Q2 2018Q4 }\end{array}$ \\
\hline Variable & Coefficient & Std. Error & t-Statistic & Prob. \\
\hline CBK_RATE & 0.005787 & 0.110117 & 0.052558 & 0.9582 \\
\hline L_RATE & 0.018084 & 0.064388 & 0.280853 & 0.7797 \\
\hline LNCPI & 2.099244 & 3.449165 & 0.608624 & 0.5449 \\
\hline LNM1 & 1.192085 & 2.513669 & 0.474241 & 0.6369 \\
\hline LNNEER & 0.818596 & 2.609931 & 0.313647 & 0.7548 \\
\hline REPO & -0.010321 & 0.086849 & -0.118835 & 0.9058 \\
\hline TBILL & -0.002968 & 0.076489 & -0.038805 & 0.9692 \\
\hline C & -15.60885 & 27.66511 & -0.564207 & 0.5745 \\
\cline { 1 - 2 } @TREND & -0.038647 & 0.063941 & -0.604413 & 0.5476 \\
\hline R-squared & 0.585308 & & & \\
\cline { 1 - 2 } Adjusted R-squared & 0.535042 & & & \\
\cline { 1 - 2 } Log likelihood & -94.64808 & & & \\
\cline { 1 - 2 } F-statistic & 11.64428 & & & \\
\cline { 1 - 2 } Prob (F-statistic) & 0.000000 & &
\end{tabular}

The results imply that there is no effect of $\mathrm{X}$ (macroeconomic variables) on $\mathrm{M}$ (investment incentives). The full mediation effect makes sense only if $\mathrm{X}$ (macroeconomic variables) significantly affects $\mathrm{M}$ (investment incentives). As cited earlier in the study, on the off chance that at least one of these connections are nonnoteworthy, the will presume that intercession isn't conceivable or likely. Since step two above is violated, there is no possible mediation effect. Therefore there is no need of proceeding to step 3 and 4 .

If a mediation effect exists, the effect of $X$ (macroeconomic variables) on $Y$ (private domestic investment) is expected to disappear (or at least weaken) when $\mathrm{M}$ (investment incentives) is included in the regression. If the effect of $\mathrm{X}$ on $\mathrm{Y}$ completely disappears, $\mathrm{M}$ fully mediates between $\mathrm{X}$ and $\mathrm{Y}$ (full mediation). If the effect of $\mathrm{X}$ on $\mathrm{Y}$ still exists, but in a smaller magnitude, $\mathrm{M}$ partially mediates between $\mathrm{X}$ and $\mathrm{Y}$ (partial mediation). The results depicted in Table 3 do not consistently support a full mediation hypothesis given that the coefficients do not consistently change in magnitude and significance. Therefore, the study does not rejected the null hypothesis that investment incentives do not meditate on the relationship between macroeconomic variables and the growth of domestic private investment in Kenya. Investment incentives are a potential explanatory variable for variations in growth private domestic investment in Kenya. A $1 \%$ increase in investment incentives (in Kenya Shillings) increases private domestic investment by $1.3 \%$. 


\section{CONCLUSIONS}

While there are a considerable number of empirical studies on the impact of macroeconomic variables on growth domestic private investments in developing countries more so in Sub Saharan Africa, this study was keen on exploring the mediating effect of investment incentives on the relationship between the relationship between macroeconomic variables and growth of private domestic investment.

This study found out that there was a positive relationship between inflation rate and growth of private domestic investment the results were significant during the period of study. This implies that private domestic investment seem to increase with increase in general price level (CPI) in the long run. This is however noted under a period of stable inflation not exceeding $6 \%$. Moderate inflation (less than 10\%), is good for economic performance and this magnifies the link between price levels and private domestic investment. The findings support the inflation targeting framework of the Central Bank of Kenya which stipulates that inflation shall be 5.0 percent, with a flexible margin of 2.5 percent on either side in the event of adverse shocks. Monetary policy therefore should seek to ensure that both internal and external shocks do not breach inflation targets. The study also supports active intervention by the CBK into financial markets to ensure inflation remains stable and within range.

The money supply was found to have a positive relationship with growth of private domestic investment the effect were significant for the period of study. The results demonstrated that private domestic investments would benefit from an increase in money supply especially increase in M1 which includes all currency in circulation, traveller's checks, demand deposit at commercial banks or other depository taking institutions held by the public, and other checkable deposits. M2 and M3 also referred to as broad money are forms of money but mostly in money market asset forms and therefore do not really reflect the volume of economic activities, unlike M1.

The study recommends innovative ways that increase the segment of the monetized economy in the country. Financial innovations that increase access to finances and ease of transactions methods especially cashless transactions platforms are crucial for private domestic investment growth. Besides, money supply aggregates (M1) is an essential component of the monetary policy implementation framework. The variation of this money supply component through monetary policy instruments e.g the critical reserve ration, Open Market Operation, and central bank rate can be useful in increasing private domestic investment to the expected levels.

The study demonstrated that increase in interest rate had a negative relationship with growth of domestic private investment the effect was also significant. The study found the need to keep the lending rates as low as possible so as to attract investors who would wish to borrow or investment. The results emphasize the role of interest rate policy and monetary policy in driving domestic private investment in Kenya. The findings of this study will be of benefit to policy makers through provision of 
data-based evidence that will be used as a guide while making appropriate policies to encourage growth of domestic private investment in the country leading to economic growth. The study advocates for policies that ensure the commercial banks remain liquid and maintain low lending rates. These policies include the liberation of the financial markets for more competition and support for more innovative but secure money lending avenues like mobile money markets. Lastly, the study recommends active financial market intervention through monetary policy to ensure commercial bank lending rates are within the conventional range for private domestic investment to thrive.

Exchange rates were found to have negatively affected growth of domestic growth in Kenya during the period of study. Depreciation increases the cost of imports especially for investment goods hence reducing private domestic investment. Secondly, depreciation induces financial outflows from the economy as investors seek more stable investment markets in the world markets. This leads to capital outflow and a reduction in private domestic investment. This study recommends for use of monetary policy interventions to preserve exchange rate stability especially against the dollar in which Kenya trades predominantly. Second, there is a need for the Central Bank to maintain the forex reserves to cover against exchange rate shocks which may impair the long-term growth in private domestic investment. Lastly, the study recommends the enactment of measures to increase exports, which in return increases dollar supply and hence appreciation of the shilling. Such measures include direct export promotions, increasing trade openness as well as incentivizing key internationally traded products like horticulture, tea, and coffee. As much as investment incentives did not mediate in the relationship between macroeconomic variables and growth of private domestic investment, the results concluded that Investment incentives are a potential explanatory variable for variations in private domestic investment in Kenya. A $1 \%$ increase in investment incentives increases domestic private domestic investment by $1.3 \%$.

The aim of this study was to offer insights to future studies in the field of macroeconomic variables, investment incentives as well as growth of domestic private investments and help policy makers and investors appreciate that foreign exchange rate is a critical component of capital flight and economic growth. More studies need to be undertaken with researchers extending the scope to more subvariables to make more informative conclusions. 


\section{References}

[1] Altaleb, G. S., \& Alokor, S. M. (2012). Economical Determinants of Domestic Investment. European Scientific Journal, ESJ, 8(7).

[2] Abdulla, A. R., Othman, M. M., \& Hongzhong, Z. (2012). An Emperical Study on the Strategies to Attract Foreign Direct Investments in Tanzania. Journal on Innovation and Sustainability. RISUS ISSN 2179-3565, 3(1), 43-52.

[3] Baron, R. \&. (1986). The moderator-mediator variable distinction in social psychological research: Conceptual, strategic, and statistical considerations. Journal of Personality and Social Psychology, 51-1173.

[4] Cherono, M. R. (2013). The effect of remittances and financial development on private investment in Kenya. Unpublished MA Economics Research Project.

[5] Gachoki, C., \& Nyang'oro, O. (2016). Impact of capital flight on private investment in Kenya. International Journal of Economics, 1(2), 1-15.

[6] Gillis, M., Perkins, D., Roemer, M., \& Snodgrass, D. (1987). Development economics.

[7] Githaiga, P. N. (2014). Do Remittances Stimulate Private Sector Investment? A Case of Sub-Saharan Africa. European Journal of Business and Management, 6, 29.

[8] Gitonga, F. K. (2017). The Relationship between Tax Incentives and Foreign Direct Investment Inflows of Listed Multinational Corporations in Kenya.

[9] Gumo, O. M. (2013). The effect of tax incentives on foreign direct investments in kenya. An unpublished MBA project, university of Nairobi.

[10] Kalu, C. U., \& Onyinye, M. O. (2015). Domestic Private Investment and Economic Growth in Nigeria: Issues and Further Consideration. International Journal of Academic Research in Business and Social Sciences, 5(2), 302.

[11] Kippra (2017). Kenya Economic Report 2017. Kenya Vision 2030.

[12] Mbaye, E. Z. (2014). Determinants of Domestic Private Investments in Kenya. Unpublished master's thesis). University of Nairobi, School of Economics, Nairobi.

[13] Kanyua, M. R. (2014). Analysis Of Determinants Of Private Investment In Kenya (Doctoral dissertation, Department of Finance and Accounts, School of Business, University of Nairobi).

[14] Mbaye, E. Z. (2014). Determinants of Domestic Private Investments in Kenya. Unpublished master's thesis). University of Nairobi, School of Economics, Nairobi.

[15] Munongo, S. (2015). The effectiveness of tax incentives in attracting foreign direct investment: the case of the Southern African Development Community (Doctoral dissertation).

[16] Musyoka K. (2012). "The relationship between tax incentives and foreign direct investment in Kenya". Unpublished MBA Project, University of Nairobi. 
[17] World Bank (2014). Macroeconomic Policy. Accessed at http://www.worldbank.org/en/topic/macroeconomics/brief/macroeconomicpolicy

[18] Mwenda, R. N. (2017). Strengthening a Vibrant Domestic Investment Market for Economic Growth in Kenya (Doctoral dissertation, United States International University-Africa). 